\title{
Utilization and planning of coastal areas in Ordu Province, Turkey
}

\author{
Konuk N.* \\ Department of Geomatics Engineering, Faculty of Engineering, Ondokuz Mayıs University, 55200, Atakum, Samsun, Turkey \\ Received: 23/05/2017, Accepted: 12/10/2017, Available online: 26/01/2018 \\ *to whom all correspondence should be addressed: e-mail: nukhetg@omu.edu.tr
}

\begin{abstract}
Coastal management is generally means planning and application of environmental changes in the coastal area. The rapid spread of industrialization, urbanization, tourism and recreational activities are affecting the coastal cities in a much more negative way in Turkey, compared to other countries. Development in infrastructure to meet the needs of the population growing in coastal areas, provision of industrial and tourism facilities or power plants, placement of main roads in the coastal zone, separation of forest areas for secondary residences or workplaces are the most important factors leading to the deterioration of the identity of coastal cities. In this study, the changes of the coastal areas in Ordu Province, one of the important touristic cities of the Black Sea Region, have been examined and evaluated. Moreover, present shoreline was investigated within the framework of Turkish Coastal Law. Finally, the variation of coastal area was determined by using the ArcMap module of ArcGIS 10 programme as numerical. The results showed that the coastal area significantly increased by filling during a short period.
\end{abstract}

Key words: Coastal zone; Coastal management; Coastal planning

\section{Introduction}

Coasts are natural areas that border water basins, such as the sea, rivers and lakes. Coastal areas are complex areas with rich natural resource potential and biodiversity, where many physical and non-physical (organizations, laws) components interact with each other and experience development pressure (Andrés et al., 2012). Because of the service they offer, coastal areas are the attraction center for many national and international uses apart distinct from other regions (Hamylton and Prosper, 2012.). Coastal zones can be considered as economic and cultural areas of the city where human activity, trade occur (Deboudt, 2011).

A significant proportion of the problems experienced in the coasts is due to population growth. It is known that $50 \%$ of the world's population lives near coast areas, and the population growth near coasts is higher than inland (CicinSain and Belfiore, 2005).

Industrialization and resulting urbanization cause a decrease the values of the coast, threaten coastal resources and this restricts the current and future coastal use of the public (Davis, 2004). Opening to the settlement of new areas to meet increasing demands on the coast, allocating more space to tourism and recreation activities, increases the carrying capacity of coastal resources. As well as being multiple use areas, coasts are seen as ideal areas for disposal of waste materials (Fletcher et al., 2007). The intensive use of the coasts causes rapid depletion of resources and causes environmental pollution, from which recovery is difficult. The coastal areas where human traffic is heavy must be developed and protected in a rational way (Christie, 2005).

In order to establish an acceptable balance between shortterm objectives and long-term assets in the development of coastal areas, according to today's common assumption, coastal processes need to be fully understood, with prudent engineering technologies and socio-economic capabilities (Wu et al., 2012). There is an urgent need to develop these areas in a controlled manner. Conflicts between various user groups are becoming increasingly apparent (Pickaver et al., 2004; Portman et al., 2012). With the increasing population density and the increasing use of earth resources, the context and dimensions of these conflicts are scaling up. A common methodology is needed that can be used to describe the complex interactions between the source system and its potential users. There is a need for planning by controlling these processes systematically and sustainably. This process is called "integrated coastal zone management" (ICZM) (Ye et al., 2014; Baquiano, 2016).

Based on its incomplete aspects and different from traditional Coastal Areas Management, ICZM has a comprehensive vision (Cooper, 2011). A modern management model has to be constituted that serves to principles of integrity, effectiveness, being scientific under institution(s) that are strong and expert in receivingimplementing-supervising of the decisions based on the balanced and sustainable profit on the coasts; that defines not only environmental and economic objectives as in traditional coastal management but also economic and social objectives; and that works multi-disciplinarily on technical, socio-economic and environmental issues (Belfiore, 2003 and Ye et al., 2015).

Integrated management of coastal areas in the context of "constant and stable progress", of which the conceptual 
frame was started to discuss in the United States in the 1970s and took on a new dimension in 1992 UN Environment Development Conference (Rio- Agenda 21) after the Mediterranean Action Plan, was adopted as a modern coastal management model that serves the principles of integrity, effectiveness and being scientific.

Turkey has approximately $7,816 \mathrm{~km}$ of the coastline length of the total $356,000 \mathrm{~km}$ of the earth. Approximately 1,017 $\mathrm{km}$ of this length belongs to the Marmara Region, 1,542 km to the Mediterranean Region, 1,695 km to the Black Sea Region, 2,671 km to the Aegean Region, and the rest belongs to the coasts of Marmara Islands, the Black Sea Islands, the Mediterranean islands and the Aegean Islands.

The rapid spread of industrialization, urbanization, tourism and recreational activities, in Turkey as in other countries, is particularly affecting the coastal cities in a more negative way. Development of infrastructure to meet the needs of the population growing in coastal areas, provision of industrial and tourism facilities or power plants, placement of main roads along the coastal zone, separation of forest areas for secondary residences or workplaces are the most important factors leading to the deterioration of the identity of coastal cities.

Ordu is a coastal province with a coastal length of $121 \mathrm{~km}$, bordered by the Terme District of Samsun in the west and the Piraziz District of Giresun in the east in the Middle Black Sea Region. Sixty kilometers of the province's coasts consist of beaches. Coasts of the province have two morphologies as elevation and bluff coasts. The elevation coast type is seen in Ordu-Fatsa, and the bluff type is seen in other areas. The elevation coastal zone is open to the north and northwest storm winds, and deep gulfs are surrounded by small coves. Perşembe harbor is a great natural shelter.

In this study, present coastal structures of Ordu province were investigated based on the land and marine boundaries of the coast. Moreover, the variation of coastal area was determined from the aerial photographs by using a programme as numerical.

\section{Methodology}

The study area is the coastal area of Ordu-Giresun Airport, which lies within the borders of the former Ordu Metropolitan Municipality, Altınordu-Rıhtım in the west and Ordu Gülyalı-Giresun Piraziz in the east. The study of the change in the use of the coastal area was carried out using the orthophotos of the years 2012-2013 and 20162017. The current coastline from Ordu's 2016-2017 orthophoto image was determined using the ArcMap module of the ArcGIS 10 program. The images in GeoTiff format were matched with the common points in the orthophoto using WGS-84 datum, and their rotations were corrected.

In order to quantify the coastlines on the used pads, vector data in the shapefile (.shp) format of field type were created from ArcGIS/ArcCatalog menu. The coastlines were digitized with the shape file in the type field of each orthophoto. After digitalization of the yearly coastlines, the common area was determined to be the maximum size for area comparisons, and parts excluding the common area were cut using the ArcMap / Editor menu.

The ArcMap/Attribute Table/Calculate Geometry module is used by the ArcMap program to calculate the coastline fields. The digitized aerial photo of each orthophoto and the generated area vector data are visualized with different colors and compared against the current orthophoto image.

\section{Results and Discussion}

Orthophoto images for 2013 and 2017 years were used to monitor the variation of the coastal area in Ordu. Figures $1(a)$ and (b) show the coastal band of the current aerial photographs according to the years indicated.

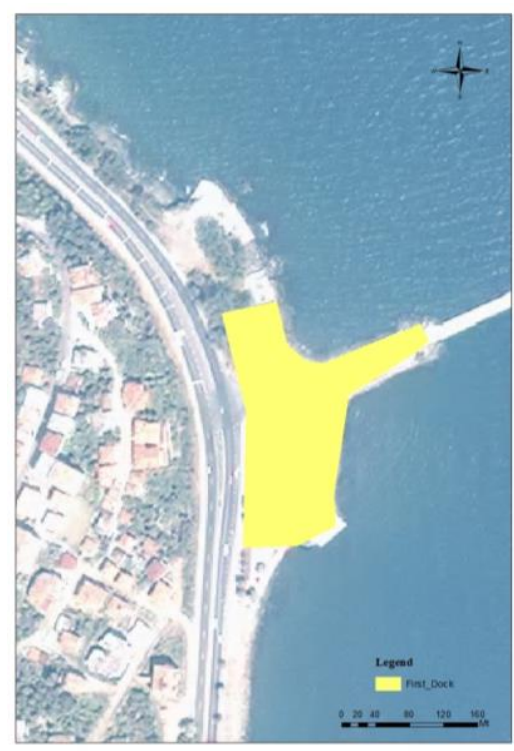

(a)

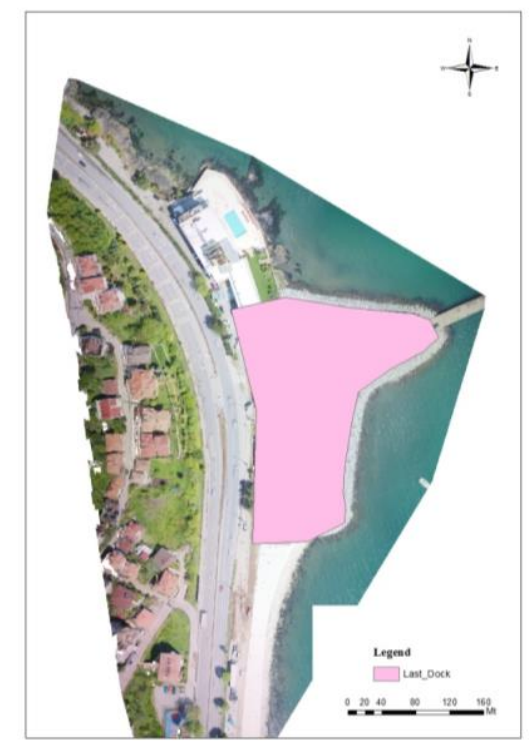

(b)

Figure 1. Orthophoto images of Ordu from the years 2012-2013 (a) and 2016-2017 (b) 
Current orthophotos images are superimposed and the changes in the coastal area are shown in Figure 2 . The numerical values calculated with the model are given in Table 1, indicating an increase in area of about $1,700 \mathrm{~m}^{2}$ in 4 year period. The field will continue to be used for recreation purposes.

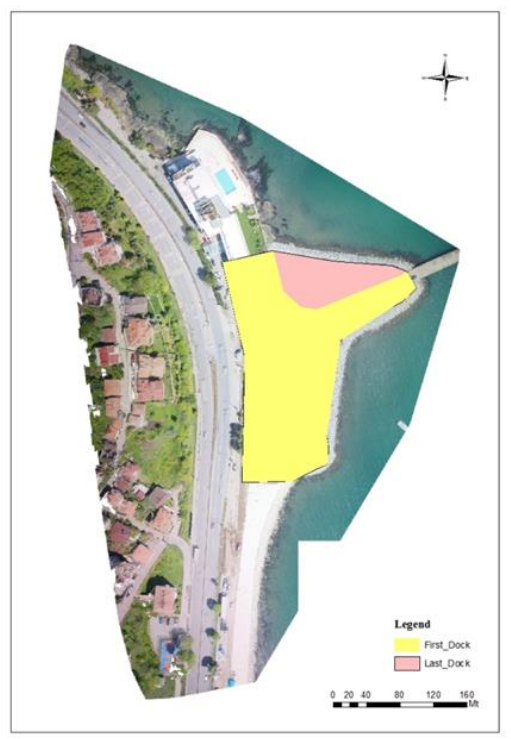

Figure 2. Coastal Line Superposition of Altınordu/Rıhtım Region

Table 1. Yearly Area Measure of Coastal Lines of Altınordu/Rıhtım Region

\begin{tabular}{cc}
\hline Years & Area Measure $\left(\mathbf{m}^{2}\right)$ \\
\hline 2013 & 8,757 \\
\hline 2017 & 10,494 \\
\hline
\end{tabular}

Ordu-Giresun Airport, located within the boundaries of Ordu and the first airport in Turkey and Europe to be built by sea reclamation, began service in May 2015. Figure 3 shows Ordu-Giresun airport reclamation area in 2013. Because there have not been any aerial photo shoots in the region because of unfavorable weather conditions in the zone, no current aerial photograph of the region exists. When the aerial photograph of the year 2013 is examined, it is seen that filling area was approximately $1,600,000 \mathrm{~m}^{2}$. According to most recent data current airport filling is $2,300,000 \mathrm{~m}^{2}$. Figure 4 shows $1 / 5000$ scale master plan of Ordu-Giresun Airport in Gülyalı district of Ordu province.

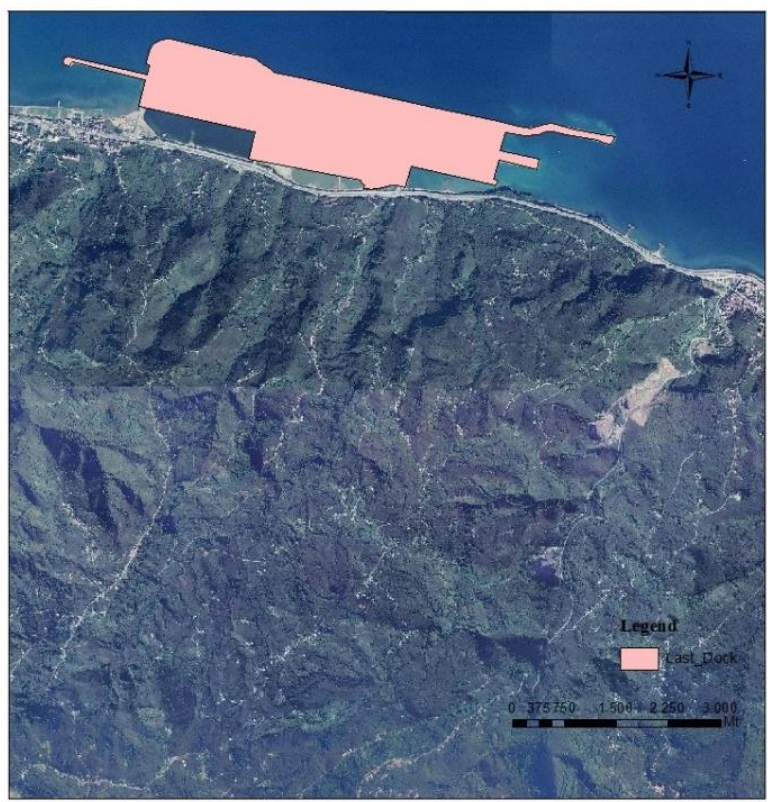

Figure 3. Ordu-Giresun Airport filling area in 2013

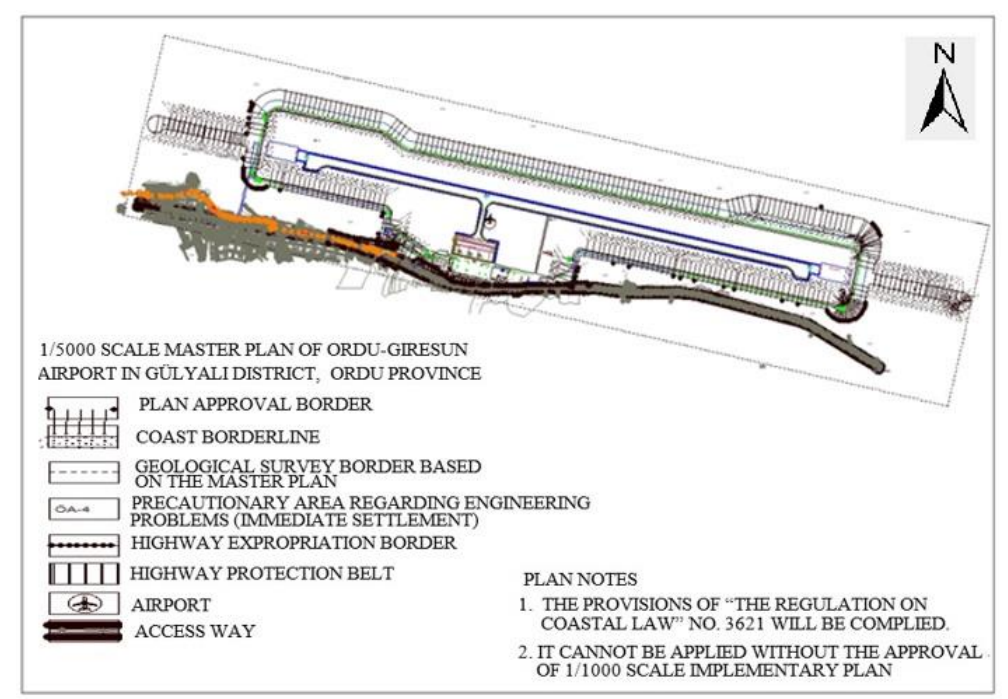

Figure 4. Master plan of Ordu-Giresun Airport in Gülyalı district of Ordu province

Unplanned exploitation of the coasts leads to multifaceted problems related to deterioration of the use and protection balance due to the inability in increasing the coastal areas. This makes coastal areas unreproducible but they may be enlarged with planned utilization and also inconsumable but they are deformed due to unplanned and unbalanced usage (Li et al., 2016). In recognizance of these problems, it is necessary to establish an effective and holistic coastal zone management mechanism to prevent these negative effects that may arise related to natural and cultural resources in the coastal areas before they occur (Maccarrone et al., 2014). 
In Turkey, Article 13 of the Regulation on the Implementation of the Coastal Law states that the following structures and facilities can be constructed according to the approved implementation development plans in the coast provided that all the measures are taken to prevent environmental pollution:

(a) Infrastructure and facilities for the public use of the coast and for the protection of coasts: ports, shelters, berths, berths, breakwaters, bridges, culverts, retaining walls, lanterns, berths, boats, salt pans, floods and pumping stations.

(b) Structures and facilities that are not possible to be built elsewhere due to the nature of their activities. Shipyards, ship dismantling, aquaculture production facilities.

(c) Also, portable showers, canopies, dressing cabins, kiosks not exceeding $6 \mathrm{~m}^{2}$ and non-polluting portable toilets without septic tank; provided that $150 \mathrm{~m}$. distance between each and wooden piers may be constructed without implementation development plans.

On the other hand, Article 17 of the same directive states that the implementation plans containing the first section of the coastlines ${ }^{1}$ are arranged in such a way that they can be allocated to the use of the whole community as open space. These areas may only include paths, walking and recreational areas, sightseeing and terrace areas and recreation uses defined in the Article 4 and structures and facilities defined in the Article 13 of this regulation. No other structures and facilities can be built in this area, including open buildings for community use. It is essential to preserve ecological balance and not to negatively affect the sea, natural and artificial lakes and rivers and their surroundings and living resources during the preparation of the plans, their evaluation, and the reclamation process.

\section{Conclusion}

In the study, the change of the coastal area in Ordu, the third largest province of the Black Sea Region in Turkey, was examined. The results have shown that there are significant increases in the coastal area during a short fouryear period. In Turkey, a separate management authority specific to coastal areas does not exist in many coastal area, including Ordu Province; rather the authority and duties of planning, evaluating and approving plans, and offering opinions are distributed among different institutions. Different legal regulations and ownership cause problems such as lack of communication and coordination among institutions. Due to this situation, inadequacies arise in the protection, use, and supervision of coastal areas. Unlawful practices cannot be prevented and effective control is impossible due to the lack of consensus resulting from the contradictions between the different legal regimes of the institutions, the confusion of authority, and the long times period for communication between institutions.

\section{References}

Andrés M., Barragán J.M. and Sanabria J.G (2017), Relationships between coastal urbanization and ecosystems in Spain, Cities, 68, 8-17.

Baquiano M. (2016), Understanding coastal resource management using a social representations approach, Ocean and Coastal Management, 133, 18-27.

Belfiore S. (2003), The growth of integrated coastal management and the role of indicators in integrated coastal management: introduction to the special issue, Ocean and Coastal Management, 46, 225-234.

Christie P. (2005), Introduction to the integrated coastal management sustainability research project theme issue, Ocean and Coastal Management, 48, 205-207.

Cicin-Sain B. and Belfiore S. (2005), Linking marine protected areas to integrated coastal and ocean management: A review of theory and practice, Ocean and Coastal Management, 48, 847-868.

Cooper J.A.G. (2011), Progress in Integrated Coastal Zone Management (ICZM) in Northern Ireland, Marine Policy, 35, 794-799.

Davis B.C. (2004), Regional planning in the US coastal zone: a comparative analysis of 15 special area plans, Ocean and Coastal Management, 47, 79-94.

Deboudt P. (2011), Testing integrated coastal zone management in France, Ocean and Coastal Management, 57, 62-78.

Fletcher S., Johnson D. and Hewett T. (2007), Coastal management in the Solent: An introduction, Marine Policy, 31, 585-590.

Hamylton S.M. and Prosper J. (2012), Development of a spatial data infrastructure for coastal management in the Amirante Islands, Seychelles, International Journal of Applied Earth Observation and Geoinformation, 19, 24-30.

Li R., Woltjer J., Brink M. and Li Y. (2016), How coastal strategic planning reflects interrelationships between ecosystem services: A four-step method, Marine Policy, 70, 114-127.

Maccarrone V., Filiciotto F., Buffa G., Mazzola S. and Buscaino G. (2014), The ICZM Balanced Scorecard: A tool for putting integrated coastal zone management into action, Marine Policy, 44, 321-334.

Pickaver A.H., Gilbert C. and Breton F. (2004), An indicator set to measure the progress in the implementation of integrated coastal zone management in Europe, Ocean and Coastal Management, 47, 449-462.

Portman M.E., Esteves L.S., Le X.Q. and Khan A.Z. (2012), Improving integration for integrated coastal zone management: An eight-country study, Science of the Total Environment, 439, 194-201.

Wu X.Q., Gao M., Wang Y., Lu Q.S. and Zhang Z.D. (2012), Framework and practice of integrated coastal zone management in Shandong Province, China, Ocean and Coastal Management, 69, 58-67.

Ye G., Chou L.M., Yang L., Yang S. and Du J. (2014), Evaluating the performance of Integrated Coastal Management in Quanzhou, Fujian, China, Ocean and Coastal Management, 96, 112-122.

Ye G., Chou L.M., Yang S., Wu J., Liu P. and Jin C. (2015), Is integrated coastal management an effective framework for promoting coastal sustainability in China's coastal cities?, Marine Policy, 56, 48-55.

width section of coastline from shoreline towards land that includes recreation areas and walkways besides whole coastline.
${ }^{1}$ According to definitions given in Article 4 of the aforementioned directive, the first section of coastlines are defined as horizontally $50 \mathrm{~m}$. 